\title{
Niobium-doped titanium dioxide nanoparticles for electron transport layers in perovskite solar cells
}

\author{
M. F. Vildanova, S. S. Kozlov, A. B. Nikolskaia, O. I. Shevaleevskiy, \\ N. A. Tsvetkov, O. V. Alexeeva, L. L. Larina \\ Department of Solar Photovoltaics, Institute of Biochemical Physics, \\ Russian Academy of Sciences, Kosygin St. 4, Moscow, 119334, Russia \\ mvildanova@sky.chph.ras.ru
}

PACS 73.63.Bd

DOI 10.17586/2220-8054-2017-8-4-540-545

\begin{abstract}
Nb-doped $\mathrm{TiO}_{2}$ nanoparticles with different doping concentrations, varied from 0 to 2.7 mol.\%, were prepared by the sol-gel method followed by thermal treatment. The obtained nanoparticles were used to fabricate a series of electron transport layers for constructing perovskite solar cells (PSCs). The prepared layers were characterized using X-ray diffraction and optical transmission measurements. The effects of Nb doping concentration in $\mathrm{TiO}_{2}$ layers on the optical absorption behavior, the morphology and charge carrier dynamics were studied. A series of PSCs, based on the developed electron transport layers was fabricated and examined. It was found that PSC fabricated with 2.7 mol.\% $\mathrm{Nb}$ content $\mathrm{TiO}_{2}$ electron transport layer have shown up to $19 \%$ improvement of a power conversion efficiency compared to that, based on an undoped $\mathrm{TiO}_{2}$ layer.
\end{abstract}

Keywords: nanoparticles, sol-gel method, $\mathrm{Nb}$-doped $\mathrm{TiO}_{2}$, thin films, semiconductors, solar photovoltaics, perovskite solar cells.

Received: 30 July 2017

Revised: 6 August 2017

\section{Introduction}

Over the last few decades, nanostructured mesoscopic layers based on metal oxide nanoparticles were successfully used for fabrication the photoelectode materials in dye-sensitized solar cells (DSCs). The same type of photoelectrode materials is also used in a new type of next generation solid-state organic-inorganic lead halide perovskite solar cells (PSCs). In both DSC and PSC photovoltaic devices the photoelectode plays a key role of the electron transport layer, transferring photogenerated charge carriers to the back contact.

In PSCs the active layer, based on perovskite film, such as $\mathrm{CH}_{3} \mathrm{NH}_{3} \mathrm{PbI}_{3}$, absorbs photons with light energy larger than their bandgap and generates the excitons that are separated into electrons and holes. The electrons are then injected into the electron transport layer. The ability of an electron transport layer to effectively transfer the photogenerated electrons diminishes the probability of their direct recombination, charge carrier accumulation at the perovskite/electrode interface and other undesirable effects that may reduce their transport characteristics [1-3].

To find a proper electron transport material for PSCs a number of metal oxides have been examined, including zinc oxide [4, 5], tin oxide [6], aluminum oxide [7] and others [8]. However, the best performance in PSCs was reached using $\mathrm{TiO}_{2}$ as an electron transport layer [9-11]. Besides that $\mathrm{TiO}_{2}$ layers show high light radiation stability and perfect electron transfer characteristics [12-14]. A well-known approach to enhance the electron conductivity of a $\mathrm{TiO}_{2}$ material, including the conductivity of the electron transport layer in PSCs, is doping with metal ions. It was reported that lithium-doped $\mathrm{TiO}_{2}$ nanoparticles were successfully used in the electron transport layer of a PSC that have shown better conductivity and improved the cell efficiency [15]. Magnesium-doped $\mathrm{TiO}_{2}$ layers have shown better photoconductivity in comparison with undoped layers, which was explained by a better band alignment at the $\mathrm{TiO}_{2}$ /perovskite interface [16]. Zinc-doped $\mathrm{TiO}_{2}$ layers have also shown better electrical conductivity than in pristine $\mathrm{TiO}_{2}$, due to the re-arrangement in the electronic structure of $\mathrm{TiO}_{2}[17,18]$. Finally, a sufficient increase of electron transport parameters was observed in niobium-doped $\mathrm{TiO}_{2}$ nanorods, used for fabrication of PSCs with improved parameters [19]. The theoretical approach describing the structure of PSCs is discussed in [20].

In our previous papers, we have prepared and examined $\mathrm{Nb}$-doped $\mathrm{TiO}_{2}$ mesoscopic electrodes for highefficiency dye-sensitized solar cells [21-23]. It was found that with the increase of $\mathrm{Nb}$ doping concentration from 0 to $3 \mathrm{~mol} . \%$ the conductivity of $10 \mu \mathrm{m}$ thick $\mathrm{TiO}_{2}$ mesoscopic layer increases, while a further increase in the doping level resulted in lower conductivity and smaller energy conversion efficiency of DSCs [23].

In the present study, we have prepared $\mathrm{Nb}$-doped $\mathrm{TiO}_{2}$ layers with different $\mathrm{Nb}$ doping concentrations and used them as electron transporting materials for PSCs fabrication. We have examined the crystal structure, optical 
absorption behavior and the morphology of Nb-doped layers. The photovoltaic performances of perovskite solar cells based on various $\mathrm{Nb}$-doped electron transporting layers are reported. The results address the issues of improving the material properties of Nb-doped layer for the fabrication of more efficient perovskite solar cells.

\section{Experimental}

\subsection{Materials and samples preparation}

$\mathrm{Nb}$-doped $\mathrm{TiO}_{2}$ particles were grown using hydrothermal method. Precursor solutions were prepared following the procedure described in [22] and the co-hydrolysis was carried out at $210{ }^{\circ} \mathrm{C}$ for $48 \mathrm{~h}$ in an autoclave. We have prepared $\mathrm{TiO}_{2}$ nanoparticles with the following $\mathrm{Nb}$ concentrations: 0.7, 1.7 and 2.7 mol.\%. Thick pastes from each of $\mathrm{Nb}$-doped $\mathrm{TiO}_{2}$ powders were fabricated according to the method reported in [24]. The pre-cleaned FTO glass substrates were first covered with $0.15 \mathrm{M}$ titanium diisopropoxide bis(ethyl acetoacetatonate) solution in 1-butanol, spin-coated at $2000 \mathrm{rpm}$ for $30 \mathrm{~s}$ and heated at $125{ }^{\circ} \mathrm{C}$ for $5 \mathrm{~min}$ to form a blocking layer. Then the prepared nanocrystalline $\mathrm{TiO}_{2}$ pastes were diluted in ethanol in a mass ratio of 1:3 and deposited on the substrate surface using spin-coating method at $2000 \mathrm{rpm}$ for $1 \mathrm{~min}$, followed by sintering at $500{ }^{\circ} \mathrm{C}$ for $1 \mathrm{~h}$. After cooling, the photoelectrodes were treated in aqueous $20 \mathrm{mM} \mathrm{TiCl} 4$ at $90{ }^{\circ} \mathrm{C}$ for $10 \mathrm{~min}$. The perovskite $\mathrm{CH}_{3} \mathrm{NH}_{3} \mathrm{PbI}_{3}$ layer was formed on the $\mathrm{TiO}_{2}$ surface under ambient atmosphere conditions by spin-coating the solution-processed single precursor [25] for $30 \mathrm{~s}$ at $4000 \mathrm{rpm}$ and then dried at $100{ }^{\circ} \mathrm{C}$ for $10 \mathrm{~min}$. The solar cell architecture was completed by depositing a commercial conductive carbon paste on the top of the perovskite film, followed by heat treatment at $100{ }^{\circ} \mathrm{C}$ for $30 \mathrm{~min}$, for preparation of the counter electrode. The active area of the photoelectrodes was $0.2 \mathrm{~cm}^{2}$.

\subsection{Characterization Studies}

$\mathrm{X}$-ray diffraction (XRD) spectra of the nanocrystalline $\mathrm{Nb}$-doped $\mathrm{TiO}_{2}$ films were obtained using DRON$3 \mathrm{M}$ (Burevestnik, Russia) diffractometer $\left(\mathrm{Cu} \mathrm{K} \mathrm{K}_{\alpha}\right.$ radiation, $\left.35 \mathrm{kV}\right)$ in the $13-65^{\circ}$ range. Optical transmittance spectra of the $\mathrm{TiO}_{2}$-based layers were recorded using a double-beam Shimadzu UV-3600 spectrophotometer with an integrating sphere ISR-3100 (Shimadzu, Japan) over a wavelength range 250-850 nm. The morphology of the films was investigated using dual-beam scanning electron microscope (SEM) Helios NanoLab 660 (FEI, USA).

The solar cells performance was evaluated by the incident photon-to-current conversion efficiency (IPCE) using QEX10 Solar Cell Quantum Efficiency Measurement System (PV Measurements, USA) and J-V measurements performed under AM1.5 incident light illumination intensity $\left(100 \mathrm{~mW} / \mathrm{cm}^{2}\right)$ using Abet Technologies Solar Simulator (Abet, USA) and Semiconductor Characterization System 4200-SCS (Keithley, USA). The power conversion efficiency $(\eta)$ of PSC was calculated according to the following equation [26]:

$$
\eta(\%)=\frac{V_{o c} \times J_{s c} \times F F}{P_{I N}} \times 100 \%,
$$

where $V_{o c}$ is open circuit voltage, $J_{s c}$ is short circuit current density, $F F$ is fill factor obtained from the $\mathrm{J}-\mathrm{V}$ curves and $P_{I N}$ is the incident light intensity. $F F$ was calculated as follows:

$$
F F=\frac{V_{\max } \times J_{\max }}{V_{o c} \times J_{s c}}
$$

where $V_{\max }$ and $J_{\max }$ are the voltage and the current density at the point of maximum power output in the $\mathrm{J}-\mathrm{V}$ curves, respectively.

\section{Results and discussion}

The $\mathrm{Nb}$ contents of the prepared $\mathrm{TiO}_{2}$ nanoparticles coincide with the doping levels. Fig. 1 shows XRD patterns of undoped and $\mathrm{Nb}$-doped $\mathrm{TiO}_{2}$ nanoparticles. It is seen that only the anatase phases of $\mathrm{TiO}_{2}$ with a (101) preferred orientation can be observed. The differences between the XRD patterns of the samples with various doping levels have not been distinguished.

The transmittance spectra of $\mathrm{Nb}$-doped $\mathrm{TiO}_{2}$ layers, given in Fig. 2, show a slight blue-shift, increasing with doping concentration. This shift denotes the increase of the $\mathrm{TiO}_{2}$ bandgap with doping from $3.0 \mathrm{eV}$ in a pristine sample to around $3.2 \mathrm{eV}$ in $2.7 \mathrm{~mol} . \% \mathrm{Nb}$-doped $\mathrm{TiO}_{2}$ as it was confirmed in [22]. The bandgap in Nb-doped $\mathrm{TiO}_{2}$ layers is known to increase with increased $\mathrm{Nb}$ doping concentration because of a slight deviation in a $\mathrm{TiO}_{2}$ lattice parameter [22]. Additionally, the position of a $\mathrm{TiO}_{2}$ conduction band-edge is increased with $\mathrm{Nb}$ doping and the conduction band position at the $\mathrm{TiO}_{2}$ /perovskite interface increases the probability of electron transfer from the photoexcited levels of perovskite to the $\mathrm{TiO}_{2}$ conduction band. 


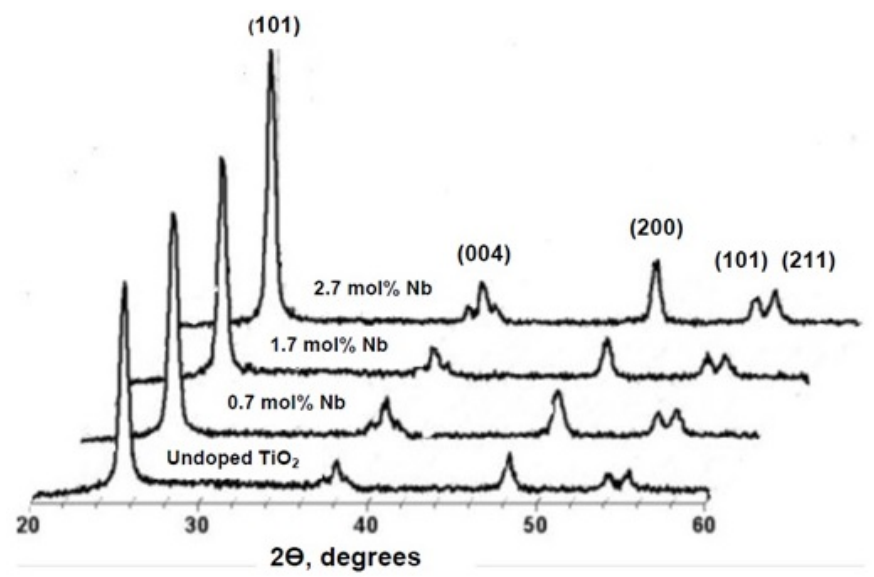

FIG. 1. XRD patterns for $\mathrm{Nb}$-doped $\mathrm{TiO}_{2}$ nanoparticles with a varied $\mathrm{Nb}$ content

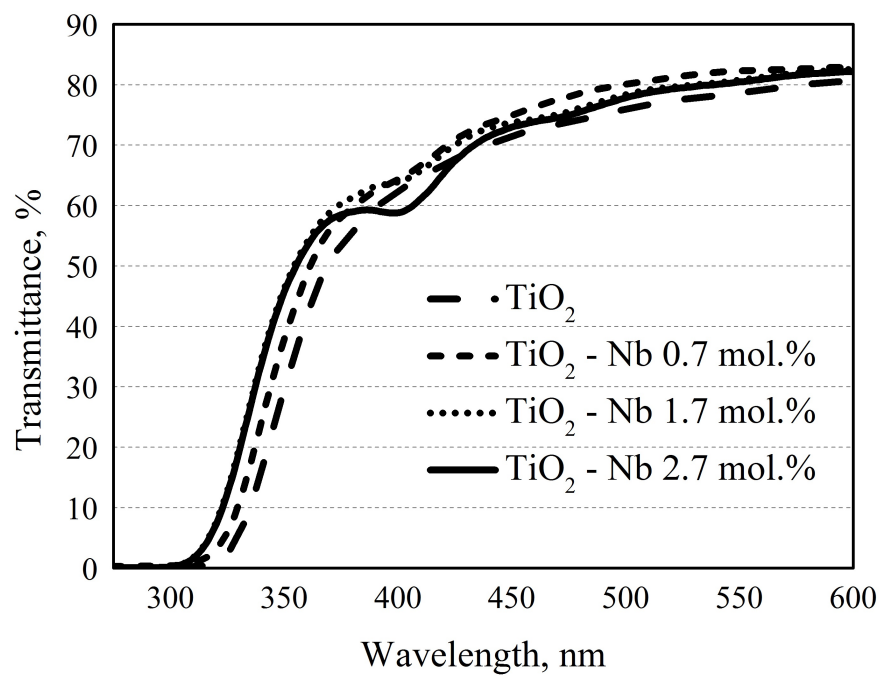

FIG. 2. Optical transmittance of $\mathrm{Nb}$-doped $\mathrm{TiO}_{2}$ layers with a varied $\mathrm{Nb}$ content

The cross-sectional SEM image, demonstrating the interfaces of the Nb-doped electron transport layer deposited on FTO glass substrate and spin-coated $\mathrm{CH}_{3} \mathrm{NH}_{3} \mathrm{PbI}_{3}$ layer for fabrication of a perovskite solar cell, is illustrated in Fig. 3. It is seen that $\mathrm{Nb}$-doped $\mathrm{TiO}_{2}$ electron transport layer with a thickness of $160 \mathrm{~nm}$ has an average grain size of around $20-40 \mathrm{~nm}$ that coincides with that of doped $\mathrm{TiO}_{2}$ nanoparticles prepared. The layer of perovskite material, with a grain size of around $300-500 \mathrm{~nm}$ and a thickness of $380 \mathrm{~nm}$, shows good adhesion to the $\mathrm{TiO}_{2}$ layer.

Using the spin-coating method for fabrication of $\mathrm{Nb}$-doped $\mathrm{TiO}_{2}$ electron transport layers with different $\mathrm{Nb}$ content, we have prepared a series of PSCs with the following configuration: FTO-glass electrode/Nb-doped $\mathrm{TiO}_{2} / \mathrm{CH}_{3} \mathrm{NH}_{3} \mathrm{PbI}_{3} /$ carbon counter electrode $\left(\mathrm{FTO} / \mathrm{TiO}_{2}(\mathrm{Nb}) / \mathrm{CH}_{3} \mathrm{NH}_{3} \mathrm{PbI}_{3} /\right.$ carbon). The appropriate schematic diagram of prepared perovskite solar cells is shown in Fig. 4.

The current-voltage measurements of the perovskite solar cells were performed under simulated AM1.5G solar radiation. Fig. 5 shows a comparative view of photocurrent density-voltage $(\mathrm{J}-\mathrm{V})$ characteristics of $\mathrm{TiO}_{2}(\mathrm{Nb}) / \mathrm{CH}_{3} \mathrm{NH}_{3} \mathrm{PbI}_{3} /$ carbon heterojunction solar cells fabricated under ambient atmosphere conditions with pristine and $2.7 \mathrm{~mol} . \% \mathrm{Nb}$-doped $\mathrm{TiO}_{2}$ electron transport layers. The highest efficiency of $5.8 \%\left(J_{s c}=15.07 \mathrm{~mA} / \mathrm{cm}^{2}\right.$, $\left.V_{o c}=0.82 \mathrm{~V}, F F=0.47\right)$ was observed for the PSC with 2.7 mol.\% Nb-doped $\mathrm{TiO}_{2}$. For the PSC based on pristine $\mathrm{TiO}_{2}$ photoelectrode, the efficiency was $4.86 \%\left(J_{s c}=13.52 \mathrm{~mA} / \mathrm{cm}^{2}, V_{o c}=0.765 \mathrm{~V}, F F=0.47\right)$. The results indicate that the best power conversion efficiency (PCE) belongs to the PSC with the above mentioned type of Nb-doped $\mathrm{TiO}_{2}$ electron transport layer. Thus, the observed PCE value was found to be up to $19 \%$ higher, than that for the PSC based on pristine $\mathrm{TiO}_{2}$ electron transport layer. Note that our experiments with a further increase 


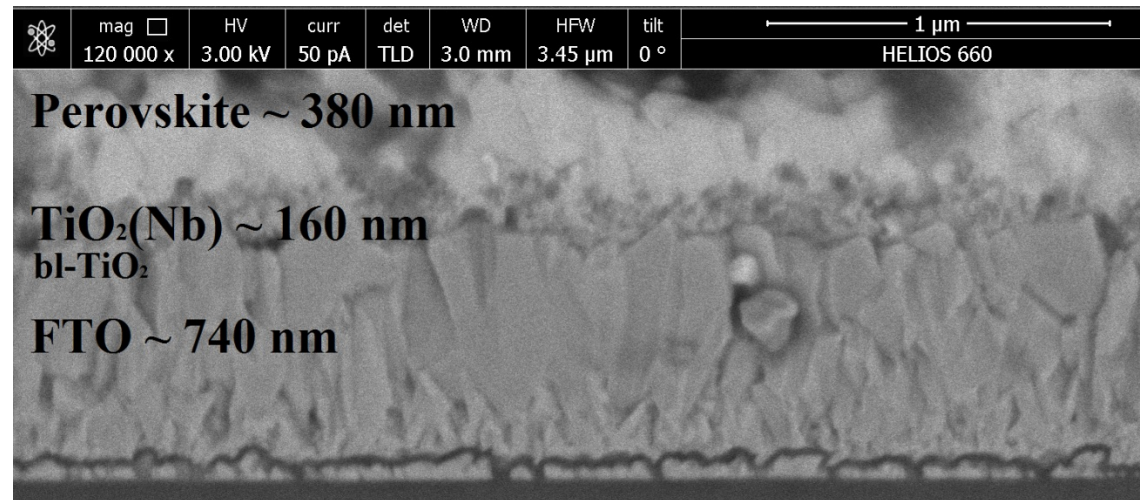

FIG. 3. Cross-sectional SEM micrograph of $\mathrm{FTO} / \mathrm{Nb}$-doped $\mathrm{TiO}_{2} / \mathrm{CH}_{3} \mathrm{NH}_{3} \mathrm{PbI}_{3}$ layers for perovskite solar cell fabrication

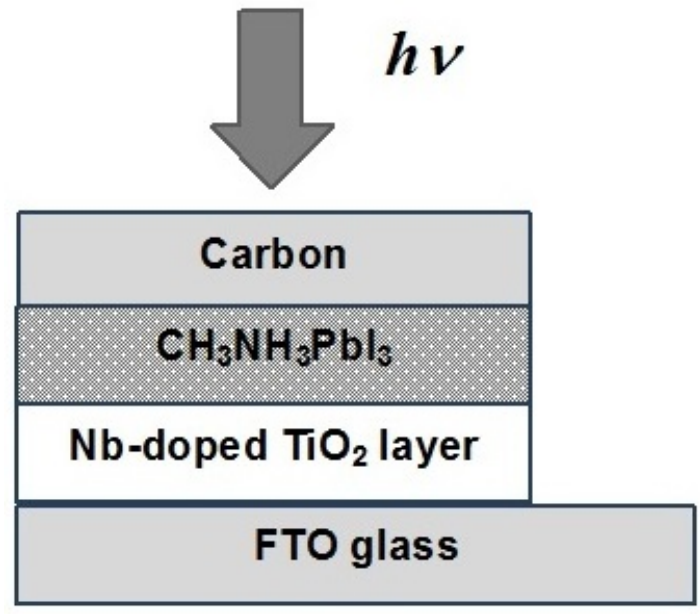

FIG. 4. The schematic diagram of a PSC structure with $\mathrm{Nb}$-doped $\mathrm{TiO}_{2}$ electron transport layer

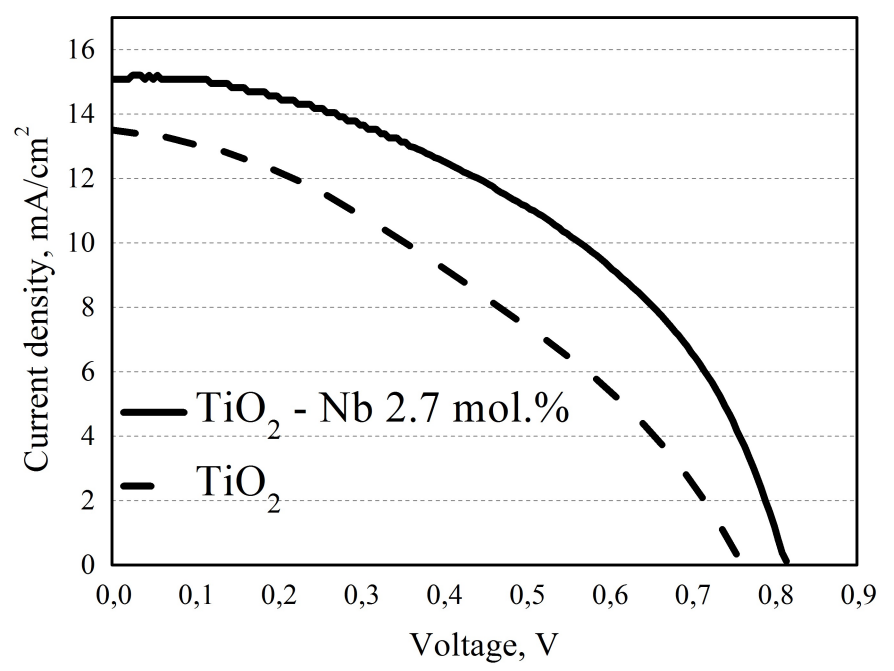

FIG. 5. J-V characteristics of the PSCs based on undoped $\mathrm{TiO}_{2}$ and a 2.7 mol.\% Nb-doped $\mathrm{TiO}_{2}$ layer 
of $\mathrm{Nb}$ doping concentration in $\mathrm{TiO}_{2}$ electron transport layers resulted in decrease of photovoltaic parameters and PCE values in the PSCs fabricated.

Figure 6 shows the IPCE spectrum for the highest performing PSC photovoltaic device based on 2.7 mol.\% $\mathrm{Nb}$-doped $\mathrm{TiO}_{2}$ electron transport layer. Spectral response values greater than $50 \%$ are obtained across the entire visible spectrum from 350 to $750 \mathrm{~nm}$.

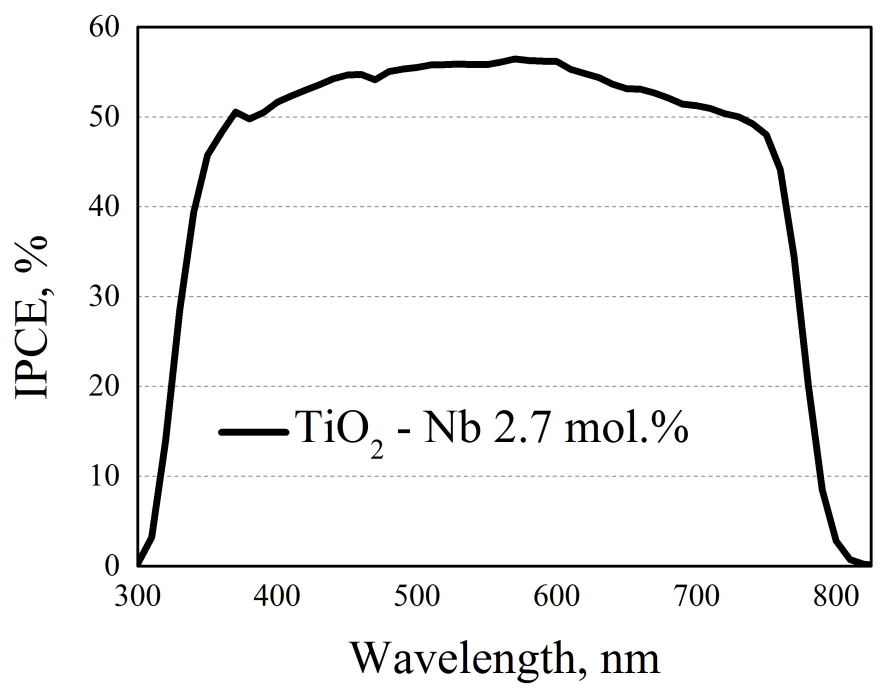

FIG. 6. IPCE spectrum of the PSC based on the $2.7 \mathrm{~mol} \% \mathrm{Nb}$-doped $\mathrm{TiO}_{2}$ electron transport layer

\section{Conclusion}

Nb-doped $\mathrm{TiO}_{2}$ nanoparticles with a $\mathrm{Nb}$ content varied between 0 and 2.7 mol.\% were prepared by cohydrolysis of $\mathrm{Ti}$ and $\mathrm{Nb}$ precursors and used for fabrication the electron transport layers in perovskite solar cells. The effects of $\mathrm{Nb}$ doping concentration in doped $\mathrm{TiO}_{2}$ layers on the changes in optical absorption behavior, the morphology and charge carrier dynamics were studied. Using the prepared layers a series of PSCs was fabricated and examined. It was found that the PSC based on $\mathrm{TiO}_{2}$ electron transport layer with a $\mathrm{Nb}$ content of $2.7 \mathrm{~mol} . \%$ have shown up to $19 \%$ improvement of a power conversion efficiency compared to that, based on an undoped $\mathrm{TiO}_{2}$ layer. Further increase in the doping concentration resulted in diminishing of the PSC power conversion parameters.

\section{Acknowledgments}

This work was supported by the Russian Science Foundation, grant No. 17-19-01776.

\section{References}

[1] Yamada Y., Nakamura T., Endo M., Wakamiya A., Kanemitsu Y. Photocarrier recombination dynamics in perovskite $\mathrm{CH}_{3} \mathrm{NH}_{3} \mathrm{PbI}_{3}$ for solar cell applications. Journal of the American Chemical Society, 2014, 136(33), P. 11610-11613.

[2] Marinova N., Tress W., Humphry-Baker R., Dar M.I., Bojinov V., Zakeeruddin S.M., Nazeeruddin M.K., Grätzel M. Light harvesting and charge recombination in $\mathrm{CH}_{3} \mathrm{NH}_{3} \mathrm{PbI}_{3}$ perovskite solar cells studied by hole transport layer thickness variation. ACS nano, 2015, 9(4), P. 4200-4209.

[3] Han G.S., Chung H.S., Kim B.J., Kim D.H., Lee J.W., Swain B.S., Mahmood K., Yoo J.S., Park N.G., Lee J.H., Jung H.S. Retarding charge recombination in perovskite solar cells using ultrathin $\mathrm{MgO}$-coated $\mathrm{TiO}_{2}$ nanoparticulate films. Journal of Materials Chemistry A, 2015, 3(17), P. 9160-9164.

[4] Son D.Y., Im J.H., Kim H.S., Park N.G. $11 \%$ efficient perovskite solar cell based on ZnO nanorods: an effective charge collection system. The Journal of Physical Chemistry C, 2014, 118(30), P. 16567-16573.

[5] Ajin Sundar S., Joseph John N., Synthesis and studies on structural and optical properties of zinc oxide and manganese-doped zinc oxide nanoparticles. Nanosystems: Physics, Chemistry, Mathematics, 2016, 7(6), P. 1024-1030.

[6] Correa Baena J.P.C., Steier L., Tress W., Saliba M., Neutzner S., Matsui T., Giordano F., Jacobsson T.J., Srimath Kandala A.R., Zakeeruddin S.M., Petrozza A., Abate A., Nazeeruddin M.K., Grätzel M., Hagfeldt A. Highly efficient planar perovskite solar cells through band alignment engineering. Energy and Environmental Science, 2015, 8(10), P. 2928-2934.

[7] Lee M.M., Teuscher J., Miyasaka T., Murakami T.N., Snaith H.J. Efficient hybrid solar cells based on meso-superstructured organometal halide perovskites. Science, 2012, 338(6107), P. 643-647. 
[8] Bi D., Moon S. J., Häggman L., Boschloo G., Yang L., Johansson E.M., Nazeeruddin M.K., Grätzel M., Hagfeldt A. Using a two-step deposition technique to prepare perovskite $\left(\mathrm{CH}_{3} \mathrm{NH}_{3} \mathrm{PbI}_{3}\right)$ for thin film solar cells based on $\mathrm{ZrO}_{2}$ and TiO $\mathrm{T}_{2}$ mesostructures. Rsc Advances, 2013, 3(41), P. 18762-18766.

[9] Su T.S., Hsieh T.Y., Hong C.Y., Wei T.C. Electrodeposited ultrathin $\mathrm{TiO}_{2}$ blocking layers for efficient perovskite solar cells. Scientific reports, 2015, 5.

[10] Murugadoss G., Mizuta G., Tanaka S., Nishino H., Umeyama T., Imahori H., Ito S. Double functions of porous TiO 2 electrodes on $\mathrm{CH}_{3} \mathrm{NH}_{3} \mathrm{PbI}_{3}$ perovskite solar cells: Enhancement of perovskite crystal transformation and prohibition of short circuiting. APL Materials, 2014, 2(8), P. 081511.

[11] Lindblad R., Bi D., Park B.W., Oscarsson J., Gorgoi M., Siegbahn H., Odelius M., Johansson E. M. J., Rensmo H. Electronic structure of $\mathrm{TiO}_{2} / \mathrm{CH}_{3} \mathrm{NH}_{3} \mathrm{PbI}_{3}$ perovskite solar cell interfaces. The journal of physical chemistry letters, 2014, 5(4), P. 648-653.

[12] Zhu T., Gao S.P. The stability, electronic structure, and optical property of $\mathrm{TiO}_{2}$ polymorphs. The Journal of Physical Chemistry C, 2014, 118(21), P. 11385-11396.

[13] Yu H., Zhang S., Zhao H., Will G., Liu P. An efficient and low-cost $\mathrm{TiO}_{2}$ compact layer for performance improvement of dye-sensitized solar cells. Electrochimica Acta, 2009, 54(4), P. 1319-1324.

[14] Van de Lagemaat J., Park N.G., Frank A.J. Influence of electrical potential distribution, charge transport, and recombination on the photopotential and photocurrent conversion efficiency of dye-sensitized nanocrystalline $\mathrm{TiO}_{2}$ solar cells: a study by electrical impedance and optical modulation techniques. The Journal of Physical Chemistry B, 2000, 104(9), P. 2044-2052.

[15] Heo J.H., You M.S., Chang M.H., Yin W., Ahn T.K., Lee S.J., Sung S.J., Kim D.H., Im S.H. Hysteresis-less mesoscopic CH $3 \mathrm{NH}_{3} \mathrm{PbI}_{3}$ perovskite hybrid solar cells by introduction of Li-treated $\mathrm{TiO}_{2}$ electrode. Nano Energy, 2015, 15, P. 530-539.

[16] Wang J., Qin M., Tao H., Ke W., Chen Z., Wan J., Qin P., Xiong L., Lei H., Yu H., Fang, G. Performance enhancement of perovskite solar cells with Mg-doped $\mathrm{TiO}_{2}$ compact film as the hole-blocking layer. Applied Physics Letters, 2015, 106(12), P. 121104.

[17] Niaki A.G., Bakhshayesh A.M., Mohammadi M.R. Double-layer dye-sensitized solar cells based on $\mathrm{Zn}^{-d o p e d ~ T i O}{ }_{2}$ transparent and light scattering layers: improving electron injection and light scattering effect. Solar Energy, 2014, 103, P. $210-222$.

[18] Zhu F., Zhang P., Wu X., Fu L., Zhang J., Xu D. The Origin of Higher Open-Circuit Voltage in Zn-Doped TiO 2 Nanoparticle-Based Dye-Sensitized Solar Cells. ChemPhysChem, 2012, 13(16), P. 3731-3737.

[19] Yang M., Guo R., Kadel K., Liu Y., O’Shea K., Bone R., Wang X., He J., Li W. Improved charge transport of Nb-doped TiO 2 nanorods in methylammonium lead iodide bromide perovskite solar cells. Journal of Materials Chemistry A, 2014, 2(46), P. 19616-19622.

[20] Oksengendler B.L., Ashurov N.R., Maksimov S E., Uralov I.Z., Karpova O.V. Fractal structures in perovskitebased solar cells. Nanosystems: Physics, Chemistry, Mathematics, 2017, 8(1), P. 92-98.

[21] Kozlov S., Nikolskaia A., Larina L., Vildanova M., Vishnev A., Shevaleevskiy O. Rare-earth and $\mathrm{Nb}_{\text {doping of TiO }} 2$ nanocrystalline mesoscopic layers for high-efficiency dye-sensitized solar cells. Physica status solidi A, 2016, 213(7), P. 1801-1806.

[22] Tsvetkov N., Larina L., Shevaleevskiy O., Ahn B.T. Electronic structure study of lightly Nb-doped TiO 2 electrode for dye-sensitized solar cells. Energy and Environmental Science, 2011, 4(4), P. 1480-1486.

[23] Tsvetkov N.A., Larina L.L., Shevaleevskiy O., Al-Ammar E.A., Ahn B.T. Design of conduction band structure of TiO 2 electrode using $\mathrm{Nb}$ doping for highly efficient dye-sensitized solar cells. Progress in Photovoltaics: Research and Applications, 2012, 20(7), P. 904-911.

[24] Ito S., Chen P., Comte P., Nazeeruddin M.K., Liska P., Péchy P., Grätzel M. Fabrication of screen-printing pastes from TiO 2 powders for dye-sensitised solar cells. Progress in photovoltaics: research and applications, 2007, 15(7), P. 603-612.

[25] Park N.G. Methodologies for high efficiency perovskite solar cells. Nano convergence, 2016, 3(1), P. 1-13.

[26] McEvoy A., Markvart T., Castañer L. Practical handbook of photovoltaics: fundamentals and applications. Elsevier, 2003. 